\title{
EGRI KÁROLY
}

\section{„URBANIZÁLÓDÓ” GOMBÁK? ADATOK ANTROPOGÉN KÖRNYEZETBEN MEGFIGYELT NAGYGOMBAFAJOKRÓL ZEMPLÉNBEN}

\begin{abstract}
Absztrakt
E munka egy sokak számára talán meglepő jelenséggel: egyes gombafajok urbanizálódott területeken történő megjelenésével foglalkozik, említést téve a Közép-Európában, illetve hazánkban történt, hasonló témájú kutatásokról is. A szerző - az utóbbi két évtizedben Sárospatakon és a település környékén végzett megfigyelései alapján - 59, antropogén környezetben talált nagygombafaj adatait közli, melyek közül 12 előfordulásának körülményeit részletezi. (Azonosításuknál, elnevezésüknél, életformájuk és esetleges vöröslista-kategóriájuk megadásánál a mikológiai szakirodalom aktuális információi voltak az irányadóak.) Elvégezve a regisztrált fajok védettségi fokozat és életforma szerinti csoportosítását, összehasonlítja az eredményeket a korábban (főként a környék különböző fás társulásaiban) folytatott kutatásainak adataival. A szerző emellett megpróbál általános áttekintést adni a nagygombák antropogén környezetben történő megjelenésének lehetséges okairól és következményeiről - kitérve néhány helyi jellegű sajátságra. Megfigyelései alátámasztják azt a tényt, hogy a vizsgált jelenség nem tekinthető egyedülállónak: a megváltozott környezethez nemcsak a növény- és állatvilág, hanem a gombák bizonyos képviselői is képesek alkalmazkodni. Mindamellett a több ezer fajt számláló hazai nagygombavilág védelmére és e gombafajok természetes élőhelyeinek megóvására továbbra is jóval nagyobb figyelmet kellene fordítani.
\end{abstract}

Kulcsszavak: nagygombafajok, urbanizáció, Zemplén

1.

\subsection{Bevezetés, előzmények, célkitüzések}

A nagygombák ideális, megszokott élőhelyének általában az érintetlen vagy legalábbis kevésbé háborgatott természeti környezetet képzelnénk. (Gondoljunk csak a receptekben 
és gasztronómiai műsorokban gyakran emlegetett, valószínűleg nem csak a szakembereket irritáló, idétlen „erdei gomba” kifejezésre!) Legfeljebb az állattenyésztéssel vagy a fakitermeléssel összefüggésben megjelenő termőtestek nem okoznak meglepetést a települések környékén. A gombák világával közelebbi kapcsolatban állóknak nem jelentenek újdonságot az urbanizálódott élőhelyeken gyakrabban felbukkanó „közönséges” nagygombafajok sem. Az már azonban a mikológusok számára is elgondolkodtató lehet, amikor ritka, speciális ökológiai igényü, vörös listás, illetőleg védett fajok rendszeres felbukkanása tapasztalható antropogén hatásoknak erősen kitett területeken.

Európában már számos kutató figyelmét felkeltették a városi környezetben megfigyelhető nagygombák. Néhány példa a környező országokból (a teljesség igénye nélkül): Németország területén (Kreisel, 1978, 2000, Benkert, 1977, Seehann, 1979) és Lengyelországban (Luszczynski, 1997 és Lawrinowycz, 1982) egyaránt vizsgálták a városokban felbukkanó nagygombákat. Több szerző hangsúlyozta a veszélyeztetett fajok magas arányát. Ausztria és az egykori Csehszlovákia településeinek viszonylatában szintén több mikológus foglalkozott azok nagygombavilágával (Wolkinger, 1982, illetve Kotlaba, 1997 és Gáper, 1996). Vizsgálataik egyik fó területét a xilofág gombák jelentették. Gáper rámutatott az urbanizáció mértéke és a taplófélék fajszáma közötti szoros összefüggésre.

Hazánkban pl. Kocsó végzett hasonló jellegü adatgyüjtést (Kocsó, 1981). Babos számos városi területről származó adatot említett munkájában (Babos, 1989). Pál-Fám Magyarországon és Erdély területén végzett ilyen irányú vizsgálatokat, ebben a talált fajok életforma szerinti csoportosítását is elvégezte (Pál-Fám, 2001). Ugyanezen kutató szerzőtársával Kaposvár belterületének nagygombavilágát térképezte fel (Pál-Fám és Boros, 2007). A munka az élőhelytípusok (pl. természetközeli területek, útszélek, kertek és parkok), a talált fajok életforma és VL-kategóriák szerinti megoszlása alapján is elemzi az összegyűjtött adatokat. Emellett általános összefüggéseket is megfogalmaz az antropogén környezet hatásaival kapcsolatban, pl. bizonyos gombafajokat az urbanizáció mértékét jelző indikátorszervezetként értékelnek. Más szerzők kutatásai (Papp, Rimóczi és Erös-Honti, 2012) a városokban gyakran ültetett platánfákat károsító taplófajok körét bővítették. Tiszaújváros zöldterületeinek gombavilágáról szintén történt adatközlés (Roffa, 2012). Kaposváry egy urbanizációs hatásoknak erősen kitett terület, a miskolci Népkert fungájának részletes vizsgálatával foglalkozik (Kaposváry, 2013). A 2008-2012 közötti időszakból 124 taxon adatait publikálja, kiemelten foglalkozik néhány ritka fajjal.

Írásom célja, hogy újabb adatokkal járuljak hozzá e jelenség vizsgálatához az utóbbi két évtizedben, főként Sárospatak területén és annak környéken végzett megfigyeléseim alapján. A Zempléni-hegység, Tokaj-Hegyalja és a Bodrogköz hármas találkozási pontjánál fekvő, patinás kisváros ugyanis nemcsak művelödéstörténeti és történelmi szempontból figyelemreméltó. Páratlanul szép természeti környezete szintén rengeteg értéket 
rejt (Hargitay, 1939, Simon, 2005 és Tuba, 1995). Ennek elválaszthatatlan részét képezi a környék nagygombavilága is, melynek nagymértékủ diverzitása a változatos környezeti tényezők kedvező hatásaként is értékelhető (Egri, 2005). Újabb vizsgálatok további értékes információkkal szolgálhatnak, akár a föld alatt termőtestet fejlesztő fajok tekintetében is (Varga, Hegyessy, Merényi, Szegedi és Bratek, 2013).

Mindezek kapcsán óhatatlanul felidéződik a Sárospataki Református Kollégium egykori diákjának, Hazslinszky Frigyesnek az emléke. A hazai botanika és mikológia egyik XIX. századi, kiemelkedő egyénisége (aki később az Eperjesi Evangélikus Kollégium tanára, majd igazgatója is lett) pedagógusként és hazafiként is diákjai példaképe volt (Egri, 2001). Természetszeretetre nevelte tanítványait is, megtalálva azt a módszert, amelynél ma sincs tökéletesebb: gyakran vitte magával őket kirándulásaira. Nem okozott számára gondot a hit és a természettudományos gondolkodás összeegyeztetése. Életrajzírója és rokona, Mágócsy-Dietz Sándor szerint az Istennel való kapcsolatot is a természetben kereste és találta meg, ott, ahol alkotásait megcsodálva a legközelebb kerülhetett hozzá (Mágócsy-Dietz, 1899).

A fajgazdag funga nem korlátozódik a természetes élőhelyekre, a település zöldterületein is megjelennek prominens képviselői. Írásomban magyarázatot kívánok adni a regisztrált fajok felbukkanására - az élőhelyek sajátságaival és az említett nagygombák életmódjával összefüggésben. Egyúttal néhány általánosabb törvényszerűség megfogalmazására is törekszem az antropogén környezet és a nagygombavilág kapcsolatát illetően. (A fajlista bővítése és részletesebb elemzése további kiterjedtebb kutatásokat igényel majd. Az urbanizálódott környezetben folyamatosan érvényesülő degradációs hatások azonban megnehezítik az adatok mennyiségi szempontú értékelését, ezért itt - megítélésem szerint - elsősorban kvalitatív vizsgálatok folytatására adódik lehetőség.)

\subsection{Anyag és módszer}

A megfigyeléseket főleg Sárospatak kertvárosi, parkosított, illetve sorházakkal/emeletes társasházakkal beépített területén - lényegében közvetlen lakókörnyezetemben - végeztem, emellett a szomszédos Sátoraljaújhelyről és környékéről is származnak adatok. A talált nagygombákról digitális felvételeket készítettem, kezdetben egy Panasonic DMC-F1-K típusú fényképezőgéppel, később pedig SAMSUNG Galaxy (Core Prime, illetve J+4) típusú mobiltelefonok kameráival. A talált termőtestek tartósítása egyszerű szárítással, illetve a módosított Herpell-féle eljárással (Bohus, 1960 és Vasas, 1993) történt. A fajok azonosításánál nagy segítséget jelentettek Phillips és Gerhardt (Vasas és Locsmándi által adaptált) kézikönyvei (Phillips, 1981, Gerhardt, Vasas és Locsmándy, 2017). Pontos meghatározásuk Moser, Hansen és Knudsen, (Moser 1983a, b, Hansen és Knudsen, 1992, 1997), valamint Rimóczi és Vetter munkái alapján történt (Rimóczi és Vetter, 1990). 
Elnevezésüknél Gerhard (Vasas és Locsmándy által adaptált, már említett) könyvét, illetve a CABI - Index Fungorum adatait használtam fel. Az életformák megállapításánál Lassoe kézikönyve (Lassoe, 1998), illetve Rimóczi munkája volt mérvadó (Rimóczi, 1994). (Olyan fajok esetében, amelyek életformája többféle is lehet, pl. lignikol szaprobionta és nekrotróf parazita, ott az általam tapasztalt jellemzőbb lett feltüntetve.) A VL-kategóriák megadásánál Magyarország nagygombáinak javasolt vörös listája (Rimóczi és mtsai., 1999) volt az irányadó. A Gombaválogató kézikönyv-sorozat egyes kötetei (Rimóczi, 2007a, b), kézikönyvei szintén értékes segítséget jelentettek az adott nagygombafajok jellemzőinek megállapításánál.

\section{Adatok antropogén területeken is észlelt nagygombafajról}

A továbbiakban néhány, a környék urbanizálódott területein megfigyelt nagygombafaj adatai (életformájuk, vörös listás fajok esetén a VL-kategória, lelőhelyük, szubsztrátumuk és a kiemelten tárgyalt fajok esetében a detektálás időpontja) következnek, kiegészítve a felbukkanás körülményeinek, lehetséges okainak részletezésével. A fejezet első részében azon nagygombák szerepelnek, amelyeket egy vagy több szempont (életforma, speciális ökológiai igények, ritkaság, az antropogén környezetben történő előfordulás érdekessége) alapján lényegesnek tartottam kiemelni. Ezt követően külön listán, latin nevük alfabetikus sorrendje szerint találhatók azoknak a gyakran tömegesen felbukkanó fajoknak az adatai, amelyeket - önmagukban - kevésbé tekintek relevánsnak (1. táblázat). Ezen nagygombák hazánkban általában közönségesnek mondhatók, természetes élőhelyeken is viszonylag gyakran megtalálhatók.

Az alkalmazott rövidítések, szimbólumok magyarázata: É.f. = életforma, St = talajlakó szaprobionta, $\mathrm{Sl}=$ lignikol szaprobionta, $\mathrm{Pn}=$ nekotróf parazita, $\mathrm{Pb}=$ biotróf parazita, Mk = mikorrhizás, $\mathrm{N}$ = mérgező , İ = jelentősebb gyógyhatással rendelkező, \$! = védetté nyilvánított

A vörös listás (VL) számok jelentése (az IUCN = International Union of Conservation of Nature) védettségi kategóriáival összefüggésben: 1 = eltűnéssel, kihalással fenyegetett (IUCN: CR, critically endangered), 2 = erősen veszélyeztetett (IUCN: EN, endangered), 3 = veszélyeztetett (IUCN = VU, vulnerable), 4 = potenciálisan veszélyeztetett (IUCN = LR, lower risk).

\subsection{Részletesebb adatok néhány nagygombafajról}

Özlábgalóca - Amanita vittadinii (Moretti) Vittadini; É.f.: St; VL: 2, \$!

A faj viszonylag gyakran figyelhető meg urbanizálódott élőhelyeken, legtöbb előfordulási 
adatom is Sárospatak belvárosi részeiről származik. Ezekből kettő a település DK-i, kertvárosi részein található füves terület. Az egyik lelőhely (2007. 09. 17., 2019. 08. 05.) a rendkívül forgalmas, lakótelepi benzinkút (Déryné u.) közvetlen közelében (!), a másik (2017. 09. 30.) pedig egy (Izsó Miklós úti) sorház előterében található. A harmadik, legtöbb (17) termőtestet produkáló élőhelyét (egy majdnem szabályos boszorkánygyürüt) az Iskolakert parkjának a vasútállomáshoz közeli sarkában figyeltem meg. (2016. 06. 19., 2019. 08. 04.) A negyedik lelőhely szintén ebben a parkban található, a másik (Kazinczy út felőli) oldalon (6. ábra). Itt két alkalommal (2018. 09. 15. és 2019. 06. 30.) sikerült néhány példányra bukkanni. (A 2018. évi adat érdekessége, hogy a rendkívül csapadékszegény időjárás ellenére jelentek meg a termőtestek.)

A fóleg mikorrhizás fajokat tartalmazó Amanita nemzetségben kivételesnek számító, terrikol szaprobionta életmód is hajlamosítja ezt a fajt az urbanizált területeken történő megjelenésre. Eredeti élőhelyei ugyanis a homokos, szikes területek és a nitrogénben dús gyepek. A települések füves, esetenként műtrágyázott vagy sókiszóródásos foltjai részben megfelelnek e faj ökológiai igényeinek. Sajnos, az őzlábgalóca védetté nyilvánítása sem sokat jelent: egy-két elöregedett példány kivételével az Iskolakertben megfigyelt mindkét boszorkánygyűrü összes termőtestét már a felvételezés utáni napokon „legombászták”. Hasonló eset következett be az ötödik, félig már külterületinek számító lelőhelyén, 2019. május 20-án is. A Bosch cég (a korábbi „Csepel”) kispataki telephelyének füvel borított részén egy „kocagombász” nézte nagy őzlábgombának, és szedte tele reklámszatyrát e galócafaj tucatnyi példányával.

Az őzlábgalóca előfordulásáról urbanizálódott területeken - pl. Miskolcon és Tiszaújvárosban - több hazai szerző is megemlékezik (Kaposvárí, 2012, Roffa, 2013). Hatékonyabb védelme már csak azért is fontos lenne, mert európai viszonylatban csak helyenként gyakori, és Magyarországon található az egyik legjelentősebb állománya (Siller és mtsai., 2006). A fentiekben említett, helyileg tapasztalt eset is jól bizonyítja azt a sajnálatos tényt, hogy a nagygombák de jure védetté nyilvánítása - önmagában nem sokat jelent. Az előfordulási adatok gyakorisága alapján célszerü volna a sárospataki Iskolakertet - mint e védett nagygombafaj kiemelt élőhelyét - fokozottabb mértékü oltalom alá vonni.

Óriás bocskorosgomba - Volvariella bombycina (Schaeff.: Fr.) Singer; É.f.: Sl; VL: 3, \$! Sárospatak belterületén két alkalommal is (2002. 07. 04., 2007. 08. 20.) sikerült néhány példányra találni, nyárfa tuskóján a Végardó Fürdőben, illetve „lábon elszáradó” mezei juharon (Acer campestre) az Iskolakertben. Mindkét alkalommal egy-egy hosszabb, aszályos periódus végén jelentek meg termőtestei, amelyeknek - feltűnő méretük és hófehér színük miatt - a védetté nyilvánítás ellenére sem sok esélye marad spóráik elterjesztésére. 
E faj természetes élőhelyeken is előfordul Sárospatak környékén. További két alkalommal bukkantam néhány példányára, mindkét esetben fehér nyár (Populus alba) tuskóján, illetve majdnem teljesen elszáradt törzsén 2008 augusztusában és 2009 szeptemberében, a város körüli ártéri erdősávokban.

\section{Óriás csiperke - Agaricus augustus Fr.;É.f.: St; VL: 2}

Sátoraljaújhelytől északra, Mikóháza közelében, az Alsóregmecre vezető Szabadság út és egyben Alsóregmec szélén sikerült egyetlen példányra rátalálni 2008. 08. 02-án, lucfenyősor alatt. Az értékes ritkaság felvételezése két lelkes zempléni gombásznak köszönhető. (A figyelmemet Gécziné Nagy Mária, az Abaúj-Zemplén Értékeiért Közhasznú Egyesület alapító tagja, a helyi természetvédelem egyik prominens képviselője hívta fel, édesapja pedig nemcsak őrizte, hanem öntözte is a kifejlődő termőtestet.) Elmondásuk alapján az egykori tsz.-telephely területén már többször is felbukkant e védendő nagygomba néhány példánya (10. ábra).

Sziki csiperke - Agaricus bernardii Quél. É.f.: St

Ezt a - hortobágyi szikes pusztákról ismert - halofil nagygombafajt 2019. 05. 29-én, városunk környékén rendkívül nagy mennyiségben sikerült megfigyelni Kispatakon, az Árpád utca, illetve az annak folytatását képező, Apróhomok felé vezető műút szélén. A korábbi, rendkívül száraz évszakokat követő, csapadékos időjárás hatására tömegesen bukkantak fel jellegzetes termőtestei. (2019. 08. 08-án, a belváros területén, a vasúti átjáró közelében néhány újabb példány került elő.) A gyakran táblásan berepedező bőrű, sokáig begöngyölt szélü, fiatalon szinte szabályos félgömb, idősebb korban pedig pogácsa alakú kalapok több kilométer hosszan követték egymást, közvetlenül az útpadka mellett. (Megjelenésük láthatóan meglepte a helyi lakosságot is, akik közül sokan nem tudták beazonosítani e nagytermetű, vastag húsú, jellegzetes illatú, vágásra narancsvörösre színeződő csiperkét. Ennek tényét bizonyította a - jóízü, ehető és árusítható - gombafaj sok leszedett és eldobott, egyébként teljesen ép, el sem öregedett termőteste.) E faj esetén az antropogén környezet kedvező hatása egyértelmű: a talajban lévő sziksót (nátrium-karbonátot) itt minden bizonnyal a téli hónapokban kiszórt és az úttest szélén összegyűlt nátrium-klorid helyettesítette.

Mezei szegfügomba - Marasmius oreades (Bolton: Fr.) Fr. É.f.: Mk

Gyakorisága ellenére kiemelten tárgyalom e fajt, ugyanis az urbanizált élőhelyek „meghódításában” az egyik legszembetűnőbb helyi példának tekinthető. A - hazánkban közönségesnek tartott - gombafaj az utóbbi két évtizedben visszaszorulóban van Zemplénben. (Ez a tény föleg akkor szembetűnő, ha korábbi, tömeges megjelenését összehasonlítjuk 
napjainkban tapasztalható előfordulásával.) Megritkulásának legfontosabb oka a trágyázott talajú legelőterületek jelentős csökkenése. Ez pedig szorosan összefügg az itteni, külterjes állattenyésztés rendszerváltás után kezdődött leépítésével. (Az 1990-es évek közepén még nem volt ritka, hogy a helyi piacon akár egy egész asztalsort is elfoglaltak a szegfügombát áruló asszonyok. Gombavizsgálóként tevékenykedve a csapadékos 1995ös évben több mázsát is átvizsgáltam e fajból.) Legelők híján ez a közismert és közkedvelt faj - legalábbis környékünkön - az utóbbi években egyre gyakrabban figyelhető meg a települések belterületein. A belvárosban megfigyelt két, jelentősebb előfordulási helye az Eszterházy Károly Egyetem Sárospataki Comenius Campusának (EKE SCC) épülete mögötti, illetve az Árpád Vezér Gimnázium és Kollégium (ÁVG) sportpályái melletti füves rész. Itt tíz-egynéhány boszorkánygyürüben is elöjöhetnek termőtestei két, $\mathrm{kb}$. $40 * 20$ m-es területen. Kisebb foltokban máshol is felbukkan (pl. az Iskolakert füves tisztásain, az Arany J. út Várkert melletti sávjában vagy a város legforgalmasabb, Hotel Bodroggal szemközti részén). Leggyakrabban a mezei cickafark (Achillea collina) közvetlen közelében jelenik meg. A talaj magasabb tápanyagtartalmát - trágyázás hiányában - valószínűleg az említett területek korábbi hasznosítása (régebbi kertművelés) okozza, illetve az utak mellé véletlenszerűn kikerülő anyagok (pl. mütrágya- és komposztmaradványok) biztosítják.

Változékony tinóru - Suilellus luridus (Schaeff.) Murr. É.f.: Mk, VL: 4

E jellegzetesen lomberdei (a Bodrogot kísérő ligeterdőkben is gyakorinak mondható) tinórufajra 2019. 05. 26-án, Kispatak belterületén (a Gárdonyi úton) sikerült rábukkannom egy tanulmányi kirándulás alkalmával. Meglepett, hogy nem találtam e gyökérkapcsolt nagygombafaj termőtesteinek közelében egyik jellegzetes fás szárú partnernövényét - pl. valamelyik tölgyfajt (Quercus) vagy a bükköt (Fagus sylvatica) - sem. A kis park területén csak juharlevelű platán (Platanus acerifolia), nyír (Betula pendula), kislevelü hárs (Tilia cordata), barkóca berkenye (Sorbus torminalis) és törökmogyoró (Corylus colurna) néhány példánya nő, szóba jöhető mikorrhizás partnerként. Az élénk sárgás-vöröses színekben pompázó, sérülés hatására jellegzetesen tintakékre elszíneződő „bolondgomba” - bár fözés után fogyasztható - nem bizonyulhatott túl étvágygerjesztönek, így „csak” a legidősebb példányt találtuk felrúgva...

Homoki tinóru - Hortiboletus bubalinus (Oolbekk et Duinn) L. Albert et Dima; É,f:: Mk Sárospatak belterületén, általában augusztus végén és szeptemberben, megfelelően csapadékos időjárás esetén rendszeresen észlelhető szórványos felbukkanása (pl. Comenius úti garázssor, Petőfi és Martinovics utcák kereszteződése). Általában nyírfa (Betula pendula) közelében találtam e hazánkban nem ritka nemezestinóru több példányára. Legutóbbi 
alkalommal 2017. 08. 23-án sikerült két termőtestet megfigyelnem az Ady E. téri parkban, fekete nyár (Populus nigra) alatt, agyagos-kavicsos talajon. Kékeszöldre színeződő termőrétege és vöröses tönkje következtében a helyi „gombaszakértők” a „disznó tinóra” gyűjtőnévvel illetik (Egri, 2009), nem fogyasztják, így nagyobb az esély a termőtestek épen maradására. (Urbanizálódott területeken történő gyakori megjelenésére utal nemzetségnevének előtagja is.)

Óriás pöfeteg - Langermannia gigantea (Batsch) Rostk. É.f.: St

A hazánkban nem túl gyakori faj a nitrogénben dús talajokat kedveli, felbukkanása antropogén hatásoknak kitett élőhelyeken (pl. szőlöültetvények, trágyázott kertek, állattartó telepek szélén) ezért nem is meglepő (Rimóczi, 2007a). Urbanizálódott területeken azonban - feltűnő mérete és ebből is adódó gasztronómiai keresettsége következtében - már eléggé ritkán találnak rá a mikológusok. Az akár $40 \mathrm{~cm}$-es átmérőt és közel 10 kg-os tömeget is elérő nagygomba fiatalon - amíg fehér a belseje - ehető, így az étkezési gombagyűjtők hőn áhított, „kapitális zsákmányává” válik. Gyakran szeletekre vágva és kirántva fogyasztják azok, akik kedvelik erőteljes, aromás ízét. Az általam ismertetett két példány előfordulási adata Sárospatak belvárosi részeiről származik. (1999. 10. 12-én a Kazinczy F. úti Szinyei-ház [Domján-ház] kertjének az ún. „Büdös-árok” partjára leérő végében - egy elöregedett termőtestet sikerült begyűjtenem. 2005. 08. 11-én a Vízikapu közelében két, teljesen fiatal példány került elö.) Az érett termőtestek gyakran hangos „böffentéssel” bocsátják útjukra több milliárdnyi spórájukat (innen származhat népies, pl. Erdélyben is használatos „lufing”, illetve „lóposzogó” elnevezése). Spóraporát régebben (sebhintőporként) vérzéscsillapításra, illetve méhkaptárak kifüstölésére is használták (A lóposzogó és a szentgyörgygomba, 2019), szembe kerülve azonban kötőhártyagyulladást okozhat. A középkorban antiafrodiziákumként is használatos volt e faj (Vetter, 2000).

\section{Hasadt pöfeteg - Mycenastrum corium (Guers) Desv. É.f.: St}

A viszonylag ritka faj eredeti élőhelyeit nitrogénben dús területek (pl. legelők és trágyadombok) jelentik. Ezek azonban - a külterjes állattenyésztés már említett visszaszorulása következtében - egyre fogyatkoznak a környéken is. Urbanizálódott területen történő itteni előfordulására érdekes példa volt egy speciális élőhely. Ezt az ÁVG falának tövében található mindössze 1-2 négyzetméternyi, agyagos talajú, madárürülékkel sűrűn beborított területet (ahol 2008. 07. 28-án sikerült néhány termőtestét megfigyelni) azóta sajnos lebetonozták. A szubsztrátumot „szolgáltató” galambpopulációnak a (jellegzetes „Makovecz-stílusban” épült) gimnázium tornacsarnokának tetőszerkezete biztosít fészkelőhelyet. (E különös kapcsolat jól szemlélteti, hogy egyes nagygombák megjelenésére - közvetve - még az építészeti irányzatok is hatást gyakorolhatnak...) A nitrogénben és 
foszforban gazdag madár-, illetve denevérürüléken előforduló gombák egyébként érdekes kutatási lehetőséget kínálnak. Jó példát jelentenek erre a Puerto Ricóból (Nieves-Rivera, Santos-Flores, Dugan és Miller, 2009) publikált adatok. Ebben a szerzők - az alacsonyabb rendü gombafajok mellett - 19 Basidio és 3 Ascomycota taxont is megemlítenek (több esetben csak a nemzetséget sikerült beazonosítaniuk).

\section{Galléros csillaggomba - Geastrum striatum DC. É.f.: St VL: 3}

A hazánkban viszonylag ritka gomba több termőtestére sikerült rábukkannom 2008. 07. 18-án, az egykori Tanítóképző Főiskola (ma EKE SCC) főkapujának közvetlen közelében, egy jegenyenyár (Populus nigra) hatalmas tuskója mellett, a füvel ritkásan benőtt, homokos-kavicsos talajon. Ezt a termőhelyet sajnos évekkel ezelőtt felszámolták, mert a Makovecz tér építése miatt teljesen leburkolták a területet. Majdnem egy évtizeddel később, 2017. 12. 10-én, majd 2018 novemberében, illetve 2019. 08. 03-án az előbbi élőhelytől kb. 100 m-re, a Sárospataki Alapfokú Művészeti Iskola (SAMI) épülete előtt (az Eötvös J. út és a Comenius út kereszteződésében), tiszafa (Taxus baccata) és ezüstfenyő (Picea pungens f. Glauca) alatt találtam meg újból néhány termőtestét. (Ezek valószínűleg korábban fejlődtek ki, és összeszáradva még hónapokig konzerválódtak.) (8. ábra)

Rőt áltrifla - Scleroderma citrinum Pers. N É.f.: Mk, VL: 4

A gyakorinak mondható mérgező pöfetegféle - tapasztalataim szerint - elöszeretettel jelenik meg urbanizálódott területeken is, főként az őszi hónapokban. (Az 1970-es évek közepén a Zempléni-hegység túloldalán fekvő Encsen, a Váci Mihály Gimnázium és Kollégium kőkerítése mellett is rendszeresen bukkantak fel termőtestei.) Sárospatak belvárosában gyakori partnernövényei valószínüsíthetően a nyír (Betula pendula) és a kislevelü hárs (Tilia cordata), ezek közelében gyakran a járdák, ösvények közelében figyelhető meg e nagygomba, kavicsos-homokos talajon. Elöregedett termőtesteinek részben földbe süllyedt maradványai még hónapokig megmaradhatnak.

Óriás bokrosgomba - Meripilus giganteus (Pers.: Fr.) P. Karst. É.f.: SI VL: 2

A - nevéhez méltóan - valóban hatalmasra nőtt termőtestcsoportokat 2017. 08. 18-án sikerült megfigyelnem a sátoraljaújhelyi vasútállomás környékén (Fasor utca). A nekrotróf parazita, illetve lignikol szaprobionta, fehérkorhasztó nagygombafaj kislevelü hárs (Tilia cordata) elkorhadó tuskóján, illetve annak közvetlen közelében több termőtestcsoportot is fejlesztett, melyek közül a legnagyobb a méteres átmérőt is elérte. (Egy kisebb példányt - hasonlóan urbanizálódott környezetben - a wimbledoni Canizzaro Park elkorhadt tuskóján is sikerült megfigyelnem 2005 augusztusában.) Bár fiatal termőtestei ehetők, szerencsére nem túl bizalomgerjesztő külsejűek (pl. nyomásra feketésre 
színeződnek), így kevésbé kelthetik fel az alkalmi és „megélhetési” gombászok étvágyát. Feltűnő méretű termőtestei miatt azonban így is veszélybe kerülhet, különösen antropogén környezetben (7. ábra).

\subsection{A többi nagygombafaj adatai}

\section{1. táblázat: A vizsgált területen gyakrabban előforduló nagygombafajok}

\begin{tabular}{|c|c|c|c|}
\hline S.sz. & Faj megnevezése, esetleges VL-kategória & É.f. & $\begin{array}{l}\text { Környezet, aljzat, lelő- } \\
\text { hely, egyéb jellemzők }\end{array}$ \\
\hline 1. & Agaricus arvensis Schaeff. - erdőszéli csiperke & St & $\begin{array}{l}\text { parkosított részeken, } \\
\text { füben }\end{array}$ \\
\hline 2. & Agaricus campestris L.: Fr. - mezei csiperke & St & útszél, füves terület \\
\hline 3. & $\begin{array}{l}\text { Agaricus xanthodermus Genev. } \\
\text { - karbolszagú csiperke }\end{array}$ & St & $\begin{array}{l}\text { útszél, füves terület, } \\
\text { lombos fák alatt, talajon }\end{array}$ \\
\hline 4. & $\begin{array}{l}\text { Agrocybe dura (Bolton: Fr.) Singer } \\
\text { - kerti rétgomba }\end{array}$ & St & útszél, füves terület \\
\hline 5. & $\begin{array}{l}\text { Armillaria mellea (Vahl.: Fr.) P. Kumm. } \\
\text { - gyűrűs tuskógomba } \\
20 \text { perc fözés nélkül } 叉 \text { ! }\end{array}$ & $\mathrm{Pb}$ & $\begin{array}{l}\text { Iskolakert, lombos fák } \\
\text { gyökerén, alkalomszerű } \\
\text { tömeges megjelenés }\end{array}$ \\
\hline 6. & $\begin{array}{l}\text { Auricularia auricula-judae (Bull.: Fr.) Wettst. } \\
\text { - júdásfülegomba }\end{array}$ & Pn & sérült kőrisfán, bodzán \\
\hline 7. & Bovista plumbea Pers.: Pers. - szürke pöfeteg & St & $\begin{array}{l}\text { füves terület (sport- } \\
\text { pályák, árvízvédelmi } \\
\text { töltések kavicsos teteje, } \\
\text { ösvények mellett) }\end{array}$ \\
\hline 8. & $\begin{array}{l}\text { Calocybe gambosa (Fr.) Donk. } \\
\text { - májusi pereszke }\end{array}$ & St & $\begin{array}{l}\text { füves terület (Kispatak), } \\
\text { Iskolakert, humuszos } \\
\text { talajon }\end{array}$ \\
\hline 9. & $\begin{array}{l}\text { Chondrostereum purpureum (Pers.: Fr.) Pouzar } \\
\text { - lilás réteggomba }\end{array}$ & $\mathrm{Sl}$ & $\begin{array}{l}\text { lombos fa (vadgesztenye } \\
\text { és nyár) tuskóján }\end{array}$ \\
\hline 10. & $\begin{array}{l}\text { Coprinopsis atramentaria (Bull.) Redhead, Vilgalys \& } \\
\text { Moncalvo - ráncos tintagomba } \underset{\rtimes}{\star} \text { alkohollal együtt }\end{array}$ & St & talaj, lombos fák tövénél \\
\hline 11. & $\begin{array}{l}\text { Coprinus comatus (Müll.: Fr.) Pers. } \\
\text { - gyapjas tintagomba }\end{array}$ & St & $\begin{array}{l}\text { útszél, parkok gyeptaka- } \\
\text { rója, homokos talaj }\end{array}$ \\
\hline 12. & $\begin{array}{l}\text { Coprinus micaceus (Bull.) Vilgalys, Hopple \& Jacq. } \\
\text { Johnson - kerti tintagomba } \underset{x}{*} \text { alkohollal együtt }\end{array}$ & $\mathrm{Sl}$ & $\begin{array}{l}\text { lombosfa-tuskón, talaj } \\
\text { korhadó faanyagán }\end{array}$ \\
\hline
\end{tabular}




\begin{tabular}{|c|c|c|c|}
\hline S.sz. & Faj megnevezése, esetleges VL-kategória & É.f. & $\begin{array}{l}\text { Környezet, aljzat, lelö- } \\
\text { hely, egyéb jellemzők }\end{array}$ \\
\hline 13. & $\begin{array}{l}\text { Entoloma clypeatum (L.: Fr.) P. Kumm. } \\
\text { - tövisaljagomba }\end{array}$ & $\mathrm{Mk}$ & $\begin{array}{l}\text { kökénybokrok alatt, } \\
\text { a bodrogközi holtágak } \\
\text { (Füzes-ér, Keleti-Bodrog- } \\
\text { holtág) közelében }\end{array}$ \\
\hline 14. & $\begin{array}{l}\text { Flammulina velutipes (Curtis.: Fr.) Singer } \\
\text { - téli fülőke }\end{array}$ & $\mathrm{Pn}$ & sérült füzfán és kőrisfán \\
\hline 15. & $\begin{array}{l}\text { Fomes fomentarius (L.: Fr.) Fr. } \\
\text { - bükkfa-tapló }\end{array}$ & $\operatorname{Pn}$ & $\begin{array}{l}\text { sérült, beteg lombos } \\
\text { fákon, kidőlt fatörzseken }\end{array}$ \\
\hline 16. & $\begin{array}{l}\text { Fomitopsis betulina (Bull.) B.K. Cui, M.L. Han \& Y.C. } \\
\text { Day - nyírfa-tapló }\end{array}$ & Pn & sérült nyírfán \\
\hline 17. & $\begin{array}{l}\text { Ganoderma applanatum (Pers.) Pat. } \\
\text { - deres tapló }\end{array}$ & $\mathrm{Pn}$ & $\begin{array}{l}\text { tuskón, sérült lombos fák } \\
\text { talajhoz közeli részein }\end{array}$ \\
\hline 18. & $\begin{array}{l}\text { Ganoderma lucidum (Fr.) P. Karst. } \\
\text { - pecsétviaszgomba }\end{array}$ & Pn & $\begin{array}{l}\text { lombos fák (vadgesztenye, } \\
\text { akác, fehér nyár, tölgyfa- } \\
\text { jok) töve, tuskója }\end{array}$ \\
\hline 19. & $\begin{array}{l}\text { Hypholoma fasciculare (Huds.: Fr.) P. Kumm. } \\
\text { - sárga kénvirággomba }\end{array}$ & $\mathrm{Sl}$ & lombos fák tuskója \\
\hline 20. & $\begin{array}{l}\text { Hypholoma lateritium (Schaeff.) P. Kumm. } \\
\text { - vöröses kénvirággomba }\end{array}$ & $\mathrm{Sl}$ & lombos fák tuskója \\
\hline 21. & $\begin{array}{l}\text { Inocybe lilacina (Peck) Kaufmann } \\
\text { - lila susulyka }\end{array}$ & $\mathrm{Mk}$ & fehér nyár alatt \\
\hline 22. & $\begin{array}{l}\text { Inonotus cuticularis (Bull.: Fr.) P. Karst. } \\
\text { - vékony rozsdástapló }\end{array}$ & Pn & $\begin{array}{l}\text { kiszáradó mezei juharon } \\
\text { és tuskóján }\end{array}$ \\
\hline 23. & $\begin{array}{l}\text { Inonotus hispidus (Bull.: Fr.) P. Karst. } \\
\text { - almafa-rozsdástapló }\end{array}$ & $\mathrm{Pb}$ & $\begin{array}{l}\text { birs, lisztes berkenye, } \\
\text { akác }\end{array}$ \\
\hline 24. & $\begin{array}{l}\text { Lactarius controversus (Pers.: Fr.) Fr. } \\
\text { - rózsáslemezủ tejelögomba }\end{array}$ & $\mathrm{Mk}$ & fehér nyár alatt, fü között \\
\hline 25. & $\begin{array}{l}\text { Laetiporus sulphureus (Bull.: Fr.) Murrill } \\
\text { - sárga gévagomba }\end{array}$ & $\mathrm{Pn}$ & $\begin{array}{l}\text { elszáradó vadcseresznyén } \\
\text { (Iskolakert) }\end{array}$ \\
\hline 26. & Lentinus tigrinus (Bull.: Fr.) Fr. - nyár-fagomba & $\mathrm{Sl}$ & $\begin{array}{l}\text { nyárfa tuskója, földbe } \\
\text { süllyedt fatörzsön, ágon }\end{array}$ \\
\hline 27. & $\begin{array}{l}\text { Lepista nuda (Bull.: Fr.) Cooke } \\
\text { - lila pereszke }\end{array}$ & St & $\begin{array}{l}\text { komposztdomb } \\
\text { (Iskolakert) áprilisi } \\
\text { megjelenés! }\end{array}$ \\
\hline 28. & Lepista personata (Fr.) Cooke - lilatönkü pereszke & St & parkok füves területein \\
\hline 29. & Lycoperdon perlatum Pers.: Pers. - bimbós pöfeteg & St & avartakarón, talajon \\
\hline
\end{tabular}




\begin{tabular}{|c|c|c|c|}
\hline S.sz. & Faj megnevezése, esetleges VL-kategória & É.f. & $\begin{array}{l}\text { Környezet, aljzat, lelö- } \\
\text { hely, egyéb jellemzők }\end{array}$ \\
\hline 30. & $\begin{array}{l}\text { Mycena galericulata (Scop.: Fr.) Quél. } \\
\text { - rózsáslemezủ kígyógomba }\end{array}$ & $\mathrm{Sl}$ & $\begin{array}{l}\text { lombos fák tuskója, } \\
\text { lehullott ágai }\end{array}$ \\
\hline 31. & $\begin{array}{l}\text { Panellus stipticus (Bull.: Fr.) P. Karst. } \\
\text { - kis áldücskőgomba }\end{array}$ & $\mathrm{Sl}$ & lombos fa tuskója \\
\hline 32. & $\begin{array}{l}\text { Paxillus involutus (Batsch.: Fr.) Fr. sensu lato } \\
\text { - begöngyöltszéluß cölöpgomba }\end{array}$ & $\mathrm{Mk}$ & nyír és lucfenyő alatt \\
\hline 33. & Phallus impudicus L.: Pers. - erdei szömörcsög & St & $\begin{array}{l}\text { Iskolakert, humuszos } \\
\text { talaj }\end{array}$ \\
\hline 34. & Phellinus igniarius (L.: Fr.) Quél. - parázstapló VL:3 & Pn & sérült füzfán és tuskóján \\
\hline 35. & $\begin{array}{l}\text { Pleurotus ostreatus (Jacq.: Fr.) P. Kumm. } \\
\text { - kései laskagomba }\end{array}$ & Pn & $\begin{array}{l}\text { sérült nyár, vadgesztenye, } \\
\text { lisztes berkenye }\end{array}$ \\
\hline 36. & $\begin{array}{l}\text { Pluteus cervinus (Schaeff.) P. Kumm. } \\
\text { - barna csengettyűgomba }\end{array}$ & $\mathrm{Sl}$ & lombos fa tuskója \\
\hline 37. & $\begin{array}{l}\text { Pluteus petasatus (Fr.) Gillet } \\
\text { - selymes csengettyűgomba }\end{array}$ & $\mathrm{Sl}$ & fürészporon \\
\hline 38. & Polyporus squamosus (Huds.) Fr. - pisztricgomba & $\mathrm{Sl}$ & $\begin{array}{l}\text { elszáradó diófán és } \\
\text { tuskóján }\end{array}$ \\
\hline 39. & $\begin{array}{l}\text { Psathyrella candolleana (Fr.: Fr.) Maire } \\
\text { - fehér porhanyósgomba }\end{array}$ & $\mathrm{Sl}$ & lombos fa tuskója \\
\hline 40. & $\begin{array}{l}\text { Psathyrella piluliformis (Bull.: Fr.) P.D. Orton } \\
\text { - barna porhanyósgomba }\end{array}$ & $\mathrm{Sl}$ & lombos fa tuskója \\
\hline 41. & $\begin{array}{l}\text { Russula fragilis (Pers.: Fr.) Fr. } \\
\text { - törékeny galambgomba }\end{array}$ & Mk & Iskolakert \\
\hline 42. & Russula heterophylla (Fr.) Fr. - dióízű galambgomba & Mk & Iskolakert \\
\hline 43. & $\begin{array}{l}\text { Schizophyllum commune Fr.: Fr. } \\
\text { - hasadtlemezu gomba }\end{array}$ & $\mathrm{Sl}$ & fatuskó, lehullott ágak \\
\hline 44. & $\begin{array}{l}\text { Trametes gibbosa (Pers.: Fr.) Fr. } \\
\text { - púpos egyrétűtapló }\end{array}$ & $\mathrm{Sl}$ & lombos fa tuskója \\
\hline 45. & Trametes versicolor (L.: Fr.) Pilát - lepketapló & $\mathrm{Sl}$ & lombos fa tuskója \\
\hline 46. & $\begin{array}{l}\text { Tricholomopsis rutilans (Schaeff.: Fr.) Singer } \\
\text { - bársonyos fapereszke }\end{array}$ & $\mathrm{Sl}$ & fenyőtuskó \\
\hline 47. & $\begin{array}{l}\text { Xylaria polymorpha (Pers.: Fr.) Grev. } \\
\text { - bunkós agancsgomba }\end{array}$ & $\mathrm{Sl}$ & fatuskó \\
\hline
\end{tabular}




\section{Következtetések}

\subsection{Az adatok értékelése}

Az eddigi megfigyelések alapján egyelőre ötvenkilenc fajról sikerült adatokat gyűjteni, de további kutatások ennek akár a többszörösét is eredményezhetik. A jelenlegi adatok tükrében is megállapíthatók az alábbiak:

1. A természetes élőhelyekkel összehasonlítva jóval kisebb a vörös listás fajok aránya (2. táblázat, 1. ábra). Korábbi munkámban (Egri, 2009) ez az arány megközelítette az 52\%-ot, jelen esetben azonban mindössze 14\%. Ez a tény is jól szemlélteti azt, hogy a - fóként napjainkra már megritkult, védelemre szoruló - fajok nagy része nem nélkülözheti a természetes ökoszisztémákban meglévő környezeti tényezőket. A nagygombák hatékony védelme nem lehetséges élőhelyük megóvása nélkül. (A háborítatlanabb, természetközeli élőhelyeken magától értetődően tapasztalható, jóval magasabb fajszám is alátámasztja ezt.)

2. Az urbanizálódott élőhelyeken a mikorrhizás fajok aránya lényegesen alacsonyabb, a parazitáké viszont jelentősen magasabb, mint a természetes/természetközeli ökoszisztémákban (3. táblázat, 3. és 4. ábra). Az antropogén környezetet jellemző folyamatos degradáció nyilvánvalóan gátolja a „wood wide web” (Jakucs, 2009) kialakulását, viszont megkönnyíti a paraziták gombafonalainak behatolását. (Az életformák megadásánál egyébként nehézséget okoz az, hogy sok faanyagot bontó, azaz xilofág nagygombafaj - a körülményektől és a lebontási folyamat előrehaladottságától függően - egyaránt viselkedhet nekrotróf parazitaként és lignikol szaprobiontaként. Ez az életformák arányának megállapításánál is okozhat kisebb eltéréseket.)

3. Az antropogén környezetben megjelenő gombafajok vizsgálata valószínűleg még kiterjedtebb kutatásokat igényel, mint a természetes élőhelyek esetében. Bár az urbanizálódott környezetben a gombák efemer életformája előnyt jelenthet, bizonyos környezeti tényezőkre érzékenyebb fajok termőtestképzése akár évekig is várathat magára. Emellett a fokozott mértékű degradáció is problémát okoz. (Az ötvenkilencből pl. mindössze egyetlen faj, a Xylaria polimorpha az Ascomycota, a többi faj a bazídiumos gombák közé tartozik. Nem véletlen ugyanakkor, hogy jelentős arányban képviseltetik magukat a - fóként évelő termőtestű - taplófélék, melyek vizsgálatával több, a bevezetőben már említett szerző is foglalkozott.) 


\subsection{A nagygombák „urbanizálódásában” szerepet játszó,}

\section{lehetséges tényezők áttekintése}

A nagygombafajok urbanizálódott területeken való megjelenésének sokféle, változatos, egymással is összefüggő oka lehet. A következőkben megpróbálkozom néhány kiemelésével és elemzésével.

1. A civilizáció fokozódó mértékü behatolása az eredetileg érintetlen vagy kevésbé degradált területekre. A nagyvárosok terjeszkedésük során, például a lakóparkok létesítésével felszabdalják és bekerítik az erdő borította élőhelyeket is. Bevásárlóközpontok, ipari parkok létesítésével pedig korábban mezőgazdasági hasznosítású külterületeket kebeleznek be. Természetes, hogy itt a gombavilág jellemző képviselői is megjelenhetnek.

2. A városi ember „zöldterületek” (parkok, játszóterek) létesítésével, karbantartásával élőhelyeket is teremt, illetve konzervál. A nagyobb településeken a hőmérsékleti és csapadékviszonyok bizonyos mértékig kiegyenlítettebbé, optimálisabbá válhatnak. Kedvező hatású például a parkok gyepének rendszeres nyírása, öntözése, a téli hideg mérséklődése, a szélerősség csökkenése.

3. A lég-, illetve talajszennyezés következtében legyengült fák egyes nekrotróf parazita (Pál-Fám és Boros, 2007) és lignikol szaprobionta fajok számára jelenthetnek megfelelő szubsztrátumot.

4. A talajt érintő antropogén hatások (komposztálás, trágyázás, mütrágya- és sószórás) szintén kedvezőek lehetnek bizonyos speciális ökológiai igényü (pl. kopro-, illetve halofil) nagygombák számára. (5. ábra)

5. A globalizáció bizonyos gombafajok elterjesztéséhez is hozzájárulhat, akár a spórák, akár a micéliumokkal részben átszőtt szubsztrátumok transzportjának segítésével. Például a bizarr külsejü, VL:1-es tintahalgomba (Clathrus archeri [Berk.] Drink.) Ausztráliából érkezett Európába, rendkívül ritkán már hazánkban is megfigyelhető (Gerhardt, Vasas és Locsmándy, 2017).

6. A termesztésbe fogott fajok mellett azok hasonló ökológiai igényü konkurensei, kísérő gombafajai is lehetőséget kaphatnak az elterjedésre. (Terpó Pomogyi, Rimóczi és Terpó, 1976) Megfelelő körülmények (megüresedő ökológiai nichek) esetén ezek szintén megjelenhetnek a városokban.

7. Bizonyos (elsősorban fátlan) társulások, élőhelytípusok eltünésével az onnan kiszoruló fajok az urbanizálódott területeken találhatnak megfelelő, új életteret maguknak. Ha ez a jelenség adott növény- és állatfajok viszonylatában megfigyelhető, akkor miért lenne kizárható egyes nagygombafajok esetében? 


\subsection{A nagygombafajok urbanizálódott területeken való megjelenésének megfigyelhető és potenciális következményei - helyi példákkal kiegészítve}

Bizonyos nagygombák felbukkanása erősen urbanizálódott területeken nem csupán érdekes, szokatlan jelenségként értékelhető. Számos közvetlen vagy későbbi következménnyel járhatnak. Ezek kisebb-nagyobb mértékben befolyásolhatják nemcsak a települések környezetét, hanem az ott lakó emberek mindennapi életét is, pozitív és negatív értelemben egyaránt.

Pozitívumként értékelhető, hogy egyes, ritkulóban lévő, vörös listás vagy akár törvényileg is védett fajok mintegy „rezervátumra” találhatnak a városokban. Mikorrhizás hálózatok kialakulására és tartós fennmaradására azonban viszonylag kevés az esély. Ezeken az antropogén hatásoknak köszönhetően létrejött élőhelyeken így főként a szaprobionta és parazita fajok kerülhetnek előnybe. Termőtesteik a nagyobb mértékủ degradáció következtében azonban ebben az esetben is fokozott veszélynek vannak kitéve. Szintén előnyösnek tekinthető a minél fajgazdagabb funga jelenléte az urbanizálódott területeken, hiszen az ökoszisztémák egészséges müködéséhez a nagygombavilág megfelelő diverzitású jelenléte is szükséges.

Fokozottan veszélyes lehet viszont a mérgező nagygombák felbukkanása, hiszen az átlagember gombaismerete egyre szegényesebbnek mondható. A mérget tartalmazó fajok, pl. a rőt áltrifla (Scleroderma citrinum) vagy a begöngyöltszélü cölöpgomba (Paxillus involutus) így szinte „házhoz jöhetnek”, fogyasztásuk meggondolatlan kipróbálására csábítva az óvatlanabb embereket, botcsinálta „szakértőket”. Utóbbi fajnál fokozott veszélyforrást jelent az a tény, hogy akkumulálódó méreganyagokat tartalmaz, amelyek a gomba első alkalommal történő elfogyasztásánál még nem feltétlenül produkálnak tüneteket. További alkalmak során azonban súlyos allergiás reakciókat, vesekárosodást, illetve hemolízist okozhatnak (Gerhardt, Vasas és Locsmándy, 2017). Az óvodák, iskolák udvarán vagy játszótereken olykor tömegesen megjelenő, akár enyhén (pl. rózsáslemezü kígyógomba - Mycena galericulata) vagy erősebben (lila susulyka - Inocybe lilacina) toxikus fajok is komoly veszélyeket rejthetnek, elsősorban a gyermekek szervezetére nézve. A gombaspórák emellett allergén tényezőként lehetnek jelen a városok levegőjében. (A spórakoncentráció tényleges mértékének és hatásainak felderítéséhez azonban alapos vizsgálatokra lenne szükség.)

A peremterületeken felbukkanó fajok közül különleges eseteket okozhatnak azok az enyhén mérgező, illetve fogyasztásra nem ajánlott fajok, pl. a karbolszagú csiperke (Agaricus xanthodermus) vagy a rózsáslemezü tejelögomba (Lactarius controversus), amelyek elfogyasztása utáni rosszullét nagyban függ az egyéni érzékenységtől. Egyes (bizonnyal erős gyomrú) vendéglátók Sárospatakon, a Keleti-Bodrog-holtág („Berek”) partján fekvő hétvégi házuk látogatóit rendszeresen kínálgatják az utóbbival arra 
hivatkozva, hogy ők már évek óta panasz nélkül fogyasztják az általuk csak „nyárfalaska" fantázianéven emlegetett gombafajt (Egri, 2009). Az ehető gombák közül például egyes csiperke- (Agaricus) vagy nagyőzlábgomba- (Macrolepiota) fajok esetében lehet veszélyes egy a környezetszennyezés következtében fellépő jelenség. Említett nemzetségek fajai ugyanis „előszeretettel” akkumulálnak termőtestükben kadmium- $\left(\mathrm{Cd}^{2+}\right)$, illetve rézionokat $\left(\mathrm{Cu}^{2+}\right)$ (Vetter, 1995). A higanyionok $\left(\mathrm{Hg}^{2+}\right)$ feldúsulása mindkét nemzetségre, emellett pedig a felsorolt nagygombák közül a gyakran fogyasztott lila pereszkére (Lepista nuda) vagy a bimbós pöfetegre (Lycoperdon perlatum) is jellemző. Előbbi fajban a $3 \mathrm{mg} / \mathrm{kg}$, utóbbiban a $9 \mathrm{mg} / \mathrm{kg}$ száraztömeg-koncentrációt is elérheti (Vetter és Berta, 1998). Bizonyos parazita fajok, pl. a diófákat is előszeretettel károsító pisztricgomba (Polyporus squamosus), a bükkfa-tapló (Fomes fomentarius) vagy a deres tapló (Ganoderma applanatum) komoly károkat okozhatnak a törzs, illetve a gyökérzet pusztításával nemcsak a monokultúrás gyümölcsösökben, hanem az utcákat szegélyező fasorokban is. Hasonló figyelhető meg az almafa-rozsdástapló (Inonotus hispidus) esetében is (9. ábra). A kidőlő fák, leszakadó ágak további veszélyforrásoknak tekinthetők.

\section{4. Összegzés}

A nagygombavilág valószínűsíthetően mindig jelen volt, van és lesz az antropogén hatásoknak kitett területeken - erre Sárospatak mint kisváros és környéke is jó példát szolgáltat. (Jelen munkámban 59 faj előfordulását említem, de kiterjedtebb és részletesebb vizsgálatok ennek minden bizonnyal akár a többszörösét is eredményeznék.) Bár a településeken belül a funga diverzitása jócskán elmarad a természetes élőhelyekétől, de jóval nagyobb annál, mint ami a folytonos degradáció következtében várható lenne. A több környezeti tényezőre nézve is tág tűrésű fajok mellett viszonylag ritka, vörös listás, sőt törvényileg védett nagygombák is megjelenhetnek/megmaradhatnak az urbanizálódott élőhelyeken. Ennek oka részben az, hogy speciális ökológiai igényeiket az ember által megváltoztatott környezet - néha egészen meglepő mértékben - képes kielégíteni. Mindez jól jelzi azt, hogy a nagygombavilág egyes képviselöi is viszonylag sikeresen adaptálódhatnak a gyors környezetváltozás következtében fellépő „evolúciós nyomáshoz”. E jelenség kapcsán azonban két tényt feltétlenül szem előtt kell tartanunk. Egyrészt nem szabad elfelednünk, hogy a több mint háromezer hazai nagygombafajnak csak elenyésző része képes az antropogén környezethez alkalmazkodni, így természetes élőhelyeik megóvása továbbra is kulcsfontosságú. (A tapasztalatok szerint egyes fajok védetté nyilvánítása - önmagában - azonban nem sokat jelent.) Másrészt az antropogén környezetben felbukkanó nagygombák újabb megoldandó környezet- és természetvédelmi, illetve gazdasági és egészségügyi kérdéseket jelenthetnek. 


\section{2. táblázat: A vörös listás nagygombafajok számának összehasonlítása}

\begin{tabular}{|l|l|l|l|l|l|}
\hline $\begin{array}{l}\text { Vizsgált élőhelyek/VL-kategóriák } \\
\text { (A*-gal jelöltek 2009-es adatok) }\end{array}$ & $\begin{array}{l}\text { VL } \\
2\end{array}$ & $\begin{array}{l}\text { VL } \\
3\end{array}$ & $\begin{array}{l}\text { VL } \\
4\end{array}$ & $\begin{array}{l}\text { VL } \\
\text { össz. }\end{array}$ & $\begin{array}{l}\text { Össz. } \\
\text { fajszám }\end{array}$ \\
\hline $\begin{array}{l}\text { Veszélyeztetett fajok száma a természetes élőhelyek- } \\
\text { kel együtt Sárospatak környékén* }\end{array}$ & 25 & 101 & 40 & 166 & 321 \\
\hline $\begin{array}{l}\text { Veszélyeztetett fajok száma Sárospatak és környéké- } \\
\text { nek urbanizálódott területein }\end{array}$ & 3 & 3 & 2 & 8 & 59 \\
\hline
\end{tabular}

120

1. ábra: A különböző VL-kategóriákba tartozó fajok számának összehasonlítása

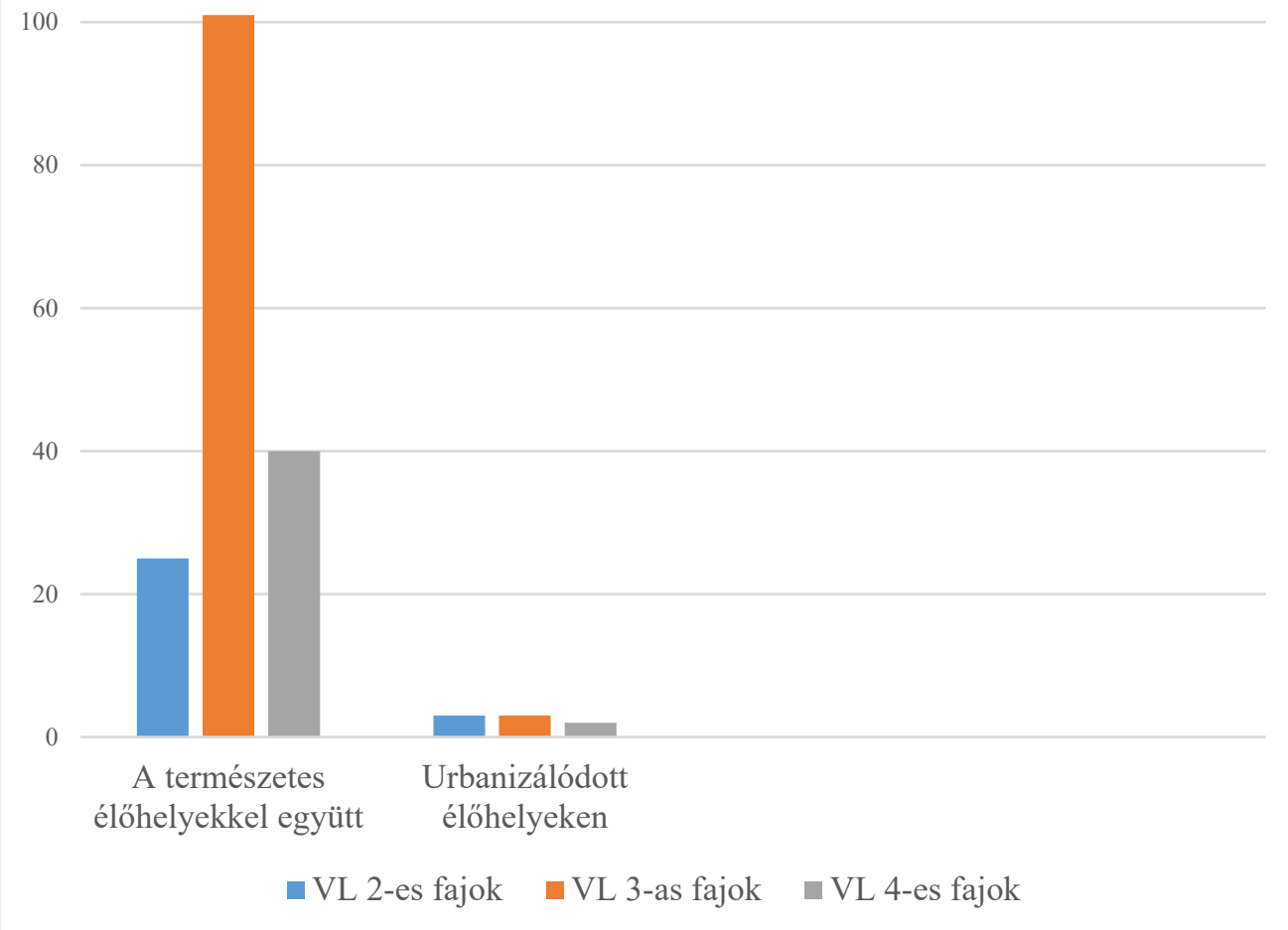




\section{3. táblázat: A nagygombafajok száma és aránya életforma szerinti megoszlásban}

\begin{tabular}{|l|c|c|c|}
\hline $\begin{array}{l}\text { Vizsgált élőhelyek/Életformák } \\
\text { (A*-gal jelöltek 2009-es adatok) }\end{array}$ & $\begin{array}{l}\text { szapro- } \\
\text { bionta }\end{array}$ & parazita & $\begin{array}{l}\text { mikorr- } \\
\text { hizás }\end{array}$ \\
\hline Fajok száma Sárospatak és környékének urbanizálódott területein & 37 & 12 & 10 \\
\hline Fajok \%-os aránya Sp. és környékének urbanizálódott területein & 63 & 20 & 17 \\
\hline Fajok száma a természetes élőhelyekkel együtt Sp. környékén * & 157 & 26 & 138 \\
\hline Fajok \%-os aránya a term. élőhelyekkel együtt Sp. környékén * & 49 & 8 & 43 \\
\hline
\end{tabular}
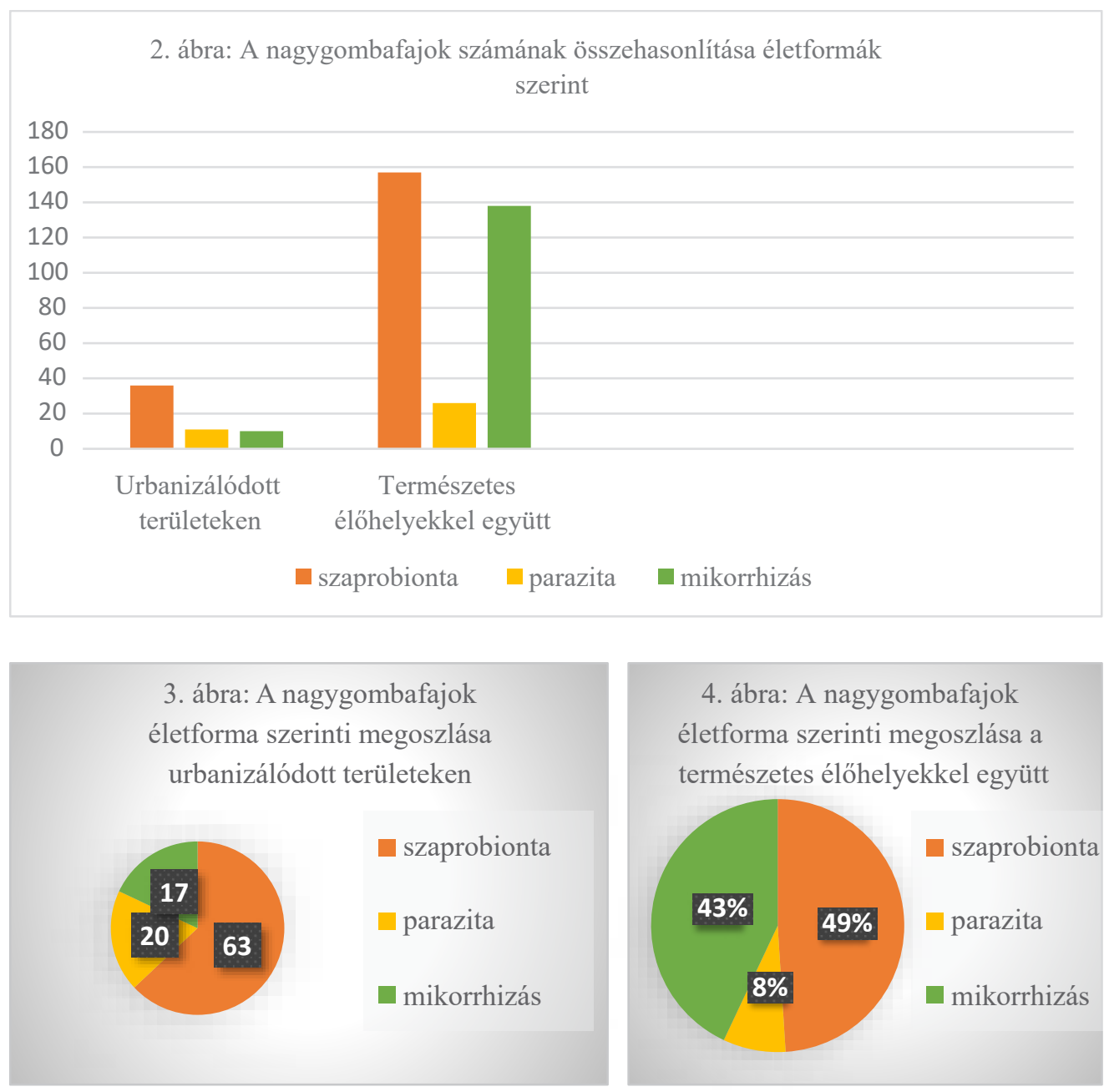


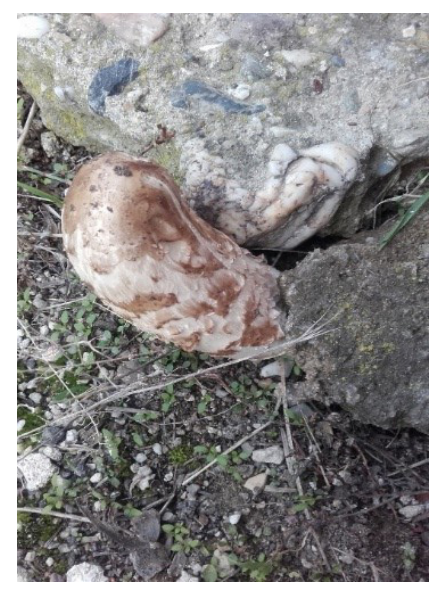

5. ábra: „Streetfighter”: a sárospataki Comenius út garázssorán a betonlap alól előtörő gyapjas tintagomba (Coprinus comatus)

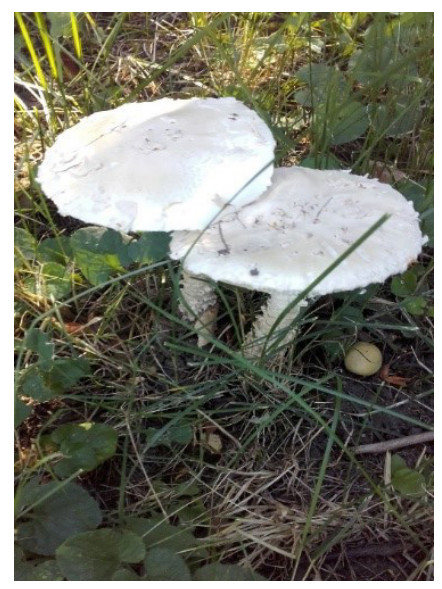

6. ábra: Özlábgalóca

(Amanita vittadinii) „duett” az Iskolakert gyepében, Sárospatakon

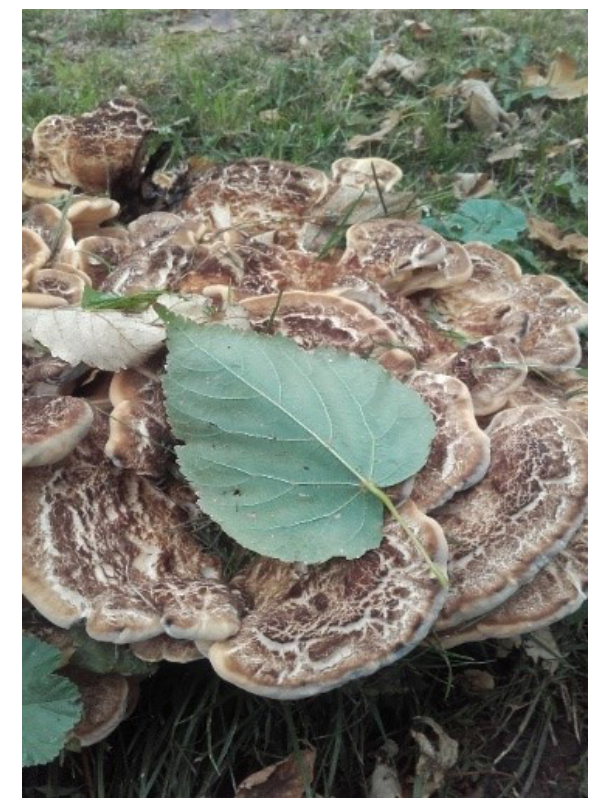

7. ábra: Valóban „gigászi” méretü óriás bokrosgomba (Meripilus giganteus)

A sátoraljaújhelyi vasútállomás közelében talált gomba termőtestcsokor átmérője megközelítette az 1 métert! 


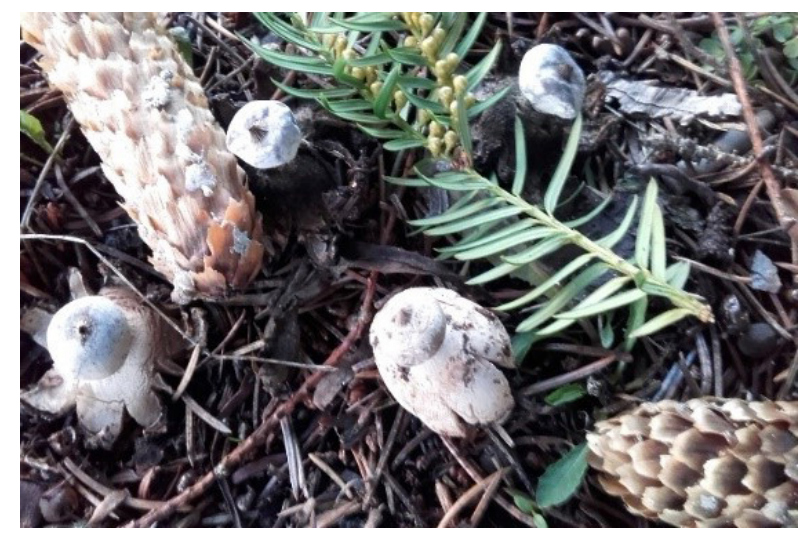

8. ábra: A galléros csillaggomba (Geastrum striatum)

Aprócska termőtestei megbújnak a Sárospataki Alapfokú Művészeti Iskola tiszafája alatt.

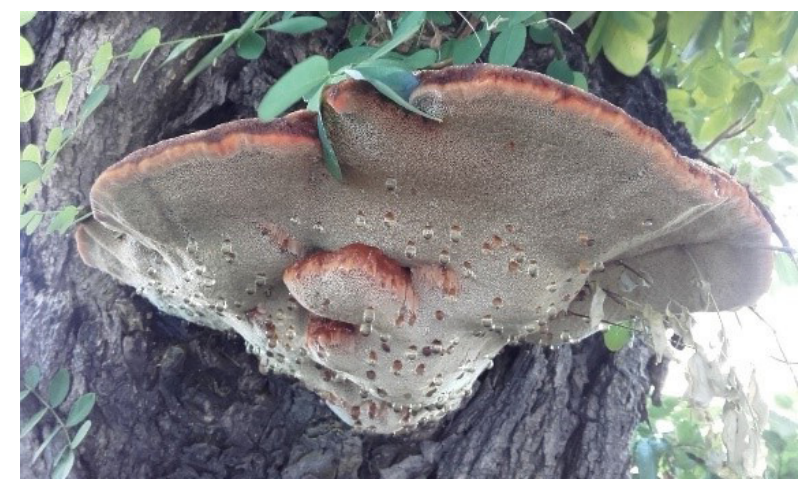

9. ábra: A sátoraljaújhelyi Esze Tamás út akácfáját károsító „könnyező” almafa-rozsdástapló (Inonotus hispidus)

Fiatal termőteste apró folyadékcseppeket választ ki a termőréteg felületén. A belőle nyerhető anyagot a szűcsök régebben bundák festésére használták (Hazslinszky, 1897). 


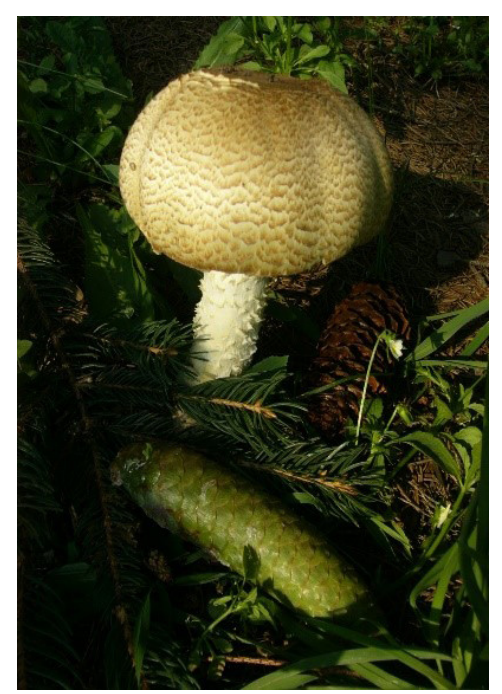

10. ábra: Az "isteni AA": óriás csiperke (Agaricus augustus) az Alsóregmec és Mikóháza közötti lucfenyősoron

A képek saját készítésűek.

\section{Irodalom}

A lóposzogó és a szentgyörgygomba (2019). https://anyanyelvcsavar.blog.hu/2019/04/12/a_ loposzogo_es_a_szentgyorgygomba (letöltve: 2019. 07.31.)

Babos, M. (1989). Magyarország kalaposgombáinak (Agaricales s.l.) jegyzéke. Mikológiai Közlemények, Clusiana, 28 (1-3), 3-324.

Benkert, D. (1977). Die Porlinge und Schichtpilze der Potsdamer Umgebung. Gleiditschia. 5. 165-202.

Bohus, G. (1973). New suggestions for preparing fleshy fungi for the herbarium. Mycologia, 55. 128-130.

CABI (2019). Index Fungorum - Species Fungorum - Search Page. Letöltés: www.speciesfungorum.org (letöltve: 2019. 08. 03.) https://doi.org/10.2307/3756389

Egri, K. (2001). XIX. századi nagy magyar mikológusok a Felvidéken: Kalchbrenner Károly és Hazslinszky Frigyes. Mikológiai Közlemények, Clusiana. 40 (1-2), 145-154. Egri, K. (2005). Adatok Sárospatak környékének nagygombáiról. Mikológiai Közlemények, Clusiana. 44 (1-2), 23-35. 
Egri, K. (2009). Sárospatak környéki nagygombák fungisztikai, ökológiai és természetvédelmi jellemzése. Doktori értekezés. phd.lib.uni-corvinus.hu/392/ (letöltve: 2019. 08. 02.) https://doi.org/10.33585/cmy.49207

Gáper, J. (1996). Polypores associated with native woody host plants in urban areas of Slovakia. Czech Mycology, 49 (2), 129-145.

Gerhardt, E, Vasas, G. és Locsmándy, Cs. (2017). Gombászok kézikönyve. CSER Kiadó, Budapest.

Hansen, L. és Knudsen, H. (1992, szerk.). Nordic Macromycetes, 2, Nordswamp, Copenhagen.

Hansen, L. és Knudsen, H. (1997, szerk.). Nordic Macromycetes 3, Nordswamp, Copenhagen.

Hazslinszky, F. (1895). Magyarhon és társországainak husos gombái. MTA. Mathematikai és természettudományi közlemények, 26, 157-370.

Hargitay, Z. (1939). A Long-erdő és vegetációja. Acta Geobotanica Hungarica, 2, 143-149.

Jakucs, E. (2009). A föld alatti gombavilág titkai. Természet Világa, 140 (9), 143-145.

Kaposváry, L. (2013). A miskolci Népkert nagygombavilágának vizsgálata. Mikológiai Közlemények, Clusiana, 52 (1-2), 5-19.

Kocsó, M. (1981): Városi zöldterületek növényeinek fóbb kárositói és kórokozói. Sopron.

Kotlaba, F. (1997). Some uncommon or rare polypores (Polyporales s.1.) collected on uncommon hosts. Czech Mycology, 50 (2), 133-142.

https://doi.org/10.33585/cmy.50207

Kreisel, H. (1978). A mikoflóra jelenlegi változásai a Német D. K.-ban. Mikológiai Közlemények, 1978 (3), 111-114.

Kreisel, H. (2000). Pilze an Strassenbäumen in Ostdeutschland. Hoppea, 61, 169-182.

Læssoe, T. (1998). Gombák. Panemex Kft. és Grafo Kft., Budapest.

Lawrynowicz, M. (1982). Macrofungal flora of Lódz. In: Bornkamm, R., Lee, J., Seaward, M. (szerk): Urban Ecology (pp. 41-47). Second European Symposium, Berlin.

Luszczynski, J. (1997). Interesting macromycetes found in the Kielce town (Central Poland). Acta Mycologica. 32 (2), 207-228. https://doi.org/10.5586/am.1997.017

Moser, M. (1983a). Die Röhrlinge und Blätterpilze. Kleine Kryptogamenflora IIb/2, Fischer Verlag, Stuttgart.

Moser, M. (1983b). Key to Agarics and Boleti. (4. kiadás) G. Fischer Verlag, Stuttgart.

Mágócsy-Dietz, S. (1899). Hazslinszky Frigyes emlékezete. Emlékbeszédek az MTA tagjairól. 9(10), 259-287.

Nieves-Rivera, Á. M., Santos-Flores, C. J., Dugan, F. M. és Miller, T. E. (2009). Guanophilic fungi in three caves of southwestern Puerto Rico. International Journal of Speleology. 38 (1), 61-70. https://doi.org/10.5038/1827-806X.38.1.7 
Pál-Fám, F. (2001). Macrofungi in human habitats. Zeszyty Naukowe 236 - Rolnictwo 47, 65-71.

Pál-Fám, F. és Boros, V. (2007). Nagygombák vizsgálata Kaposvár városában. Somogyi Múzeumok Közleményei, 17, 7-16.

Papp, V., Rimóczi, I. és Erős-Honti, Zs. (2012). Adatok a hazai és európai platánok (Platanus spp.) taplóihoz. Növényvédelem, 48 (9), 405-411.

Phillips, R. (1981). Mushrooms and other fungi of Great Britain and Europe. Pan MacMillan Ltd., London.

Rimóczi, I. és Vetter, J. (1990, szerk.). Gombahatározó I-II. Országos Erdészeti Egyesület Mikológiai Társasága, Budapest.

Rimóczi, I. (1994). Nagygombáink cönológiai és ökológiai jellemzése. Mikológiai Közlemények, Clusiana, 33(1-2), 5-180.

Rimóczi I., Siller, I., Vasas, G., Albert, L., Vetter, J. és Bratek, Z. (1999). Magyarország nagygombáinak javasolt Vörös Listája. Mikológiai Közlemények, Clusiana. 38 (1-3), 107-132.

Rimóczi. I. (2007a). Gombaválogató 1. Szaktudás Ház Kiadó Rt., Budapest.

Rimóczi. I. (2007b). Gombaválogató 2. Szaktudás Ház Kiadó Rt., Budapest.

Roffa, H. (2012). Tiszaújváros zöldterületeinek gombafaj-vizsgálata és összehasonlítása a miskolci Népkert gombafajaival. Főiskolai dolgozat, EKTF, Eger.

Seehann, G. (1979). Holzzerstörende Pilze an Strasse und Parkbaume in Hamburg. Mitteilungen der Deutschen Dendrologischen Gesselschaft. 71, 93-321.

Siller, I., Dima, B., Albert, L., Vasas, G., Fodor, L., Pál-Fám, F., Bratek, Z. és Zagyva, I. (2006): Védett nagygombafajok Magyarországon. Mikológiai Közlemények, Clusiana. 45(1-3), 3-158.

Simon, T. (2006). A Zempléni-hegység botanikai értékei. Folia Historico-naturalia Musei Matraensis. 30, 407-414.

Terpó Pomogyi, M., Rimóczi, I. és Terpó, A. (1976). Adatok a gyomjellegű nagygombák jellemzéséhez és kártételéhez. Botanikai Közlemények, 63 (1), 7-15.

Tuba, Z. (1995). Overview of the flora and vegetation of the Hungarian Bodrogköz. Tiscia. 29, 11-17.

Vasas, G. (1993). A gombák régi és új konzerválási módja a Magyar Természettudományi Múzeum Növénytárában. Mikológiai Közlemények, Clusiana. 32 (1-2), 33-42.

Vetter, J. (1993). Gyógyító gombák. Gyógyszerészet, 37, 945-949.

Vetter, J. (1995). Mérgezett gombák. Élet és Tudomány. 42, 1320-1332.

Vetter, J. és Berta, E. (1998). Hazai adatok ehető nagygombafajok higanytartalmáról. Mikológiai Közlemények, Clusiana. 37 (1-3), 71-80. 
Wolkinger, F. (1973). Holzzerstörende Basidiomyceten auf Aesculus hippocastanum und Sophora japonica im Stadgebiet von Graz. Mitteilungendes Naturwissenschaftlichen Vereines für Steiermark. 103, 205-220.

Varga, T., Hegyessy, G., Merényi, Zs., Szegedi, Zs. és Bratek, Z. (2013). Föld alatti gombák Magyarország tájain I. Tokaj-Zempléni hegvidék. Mikológiai Közlemények, Clusiana. 52 (1-2), 65-78.

Név: dr. Egri Károly PhD

Munkahely: Sárospataki Árpád Vezér Gimnázium és Kollégium

Beosztás/foglalkozás: kutatótanár

e-mail: egri.karoly.26@gmail.com

Szakmai bemutatkozás: Egri Károly tanári pályafutása az abaújszántói Gyárfás József Mezőgazdasági Szakközépiskolában kezdődött 1987-ben, majd a közel fél évezredes múltra visszatekintő Sárospataki Református Kollégium Gimnáziumában folytatódott, ahol szaktárgyait angol nyelven is oktatta. Jelenlegi munkahelyén az Arany János Tehetséggondozó Program keretén belül a természettudományos alapismeretek országos munkaközösség-vezetőjeként is tevékenykedett, kidolgozva a tárgy tanterveit és oktatási segédanyagát. 2005-től rendszeresen vesz részt az emelt szintű biológia és kémia érettségi vizsgák tantárgyi bizottságainak munkájában, általában azok elnökeként.

Sárospatak környéki nagygombák fungisztikai, ökológiai és természetvédelmi jellemzése címü doktori értekezésének nyilvános vitájára 2009. szeptember 21-én a Budapesti Corvinus Egyetem Kertészettudományi Karán került sor „summa cum laude” minősítéssel. Partnerintézményében, az Eszterházy Károly Egyetem Sárospataki Comenius Campusán 2014-2018 között oktatta a tanító és óvodapedagógus szakos hallgatóknak A felépités és müködés kapcsolata a természetben, a Megfigyelések, vizsgálódások a természetben, illetve $A z$ ember megismerése és egészsége címü tárgyakat.

2016-tól kutatótanárként tevékenykedik, komplex kutatási területének a környék nagygombái mellett a kémiai félmikro tanulókísérleti eljárások, játékos kísérleti eszközök és szemléltetési módszerek kifejlesztése is részét képezik. Emellett a régió egyedülálló természeti környezetéhez kapcsolódó tradicionális értékeinek felkutatásával, megismertetésével is foglalkozik. 2010-től tagja az MTA köztestületének. 